\title{
Analyzing the temporal location of employment centers relative to residential areas in Cape Town: A spatial metrics approach
}

\author{
Hazvinei T. Tamuka Moyo \\ University of Cape Town \\ tmkhaz001@myuct.ac.za
}

\author{
Mark H. Zuidgeest \\ University of Cape Town \\ mark.zuidgeest@uct.ac.za
}

\begin{abstract}
The marginalization of low-income earners, in regard to access to economic activities, is a topical issue in South Africa. The location of residential areas relative to locations of employment plays a large role in determining how accessible employment opportunities are to individuals. This has led to several studies that look at the polarization of growth in places of economic activities in more affluent suburbs within the discourse of social exclusion and transformation. Since South African independence, several policies were drafted to address issues of segregation and social exclusion, among other issues. However, the question remains whether there has been progress in addressing these issues. This research applies landscape metrics to understand the growth trends in the spatial location of residential areas, relative to centers of economic activities, from 1995 (start of democracy) to 2013. The analyses reveal that high-and middle-income residential areas are typically located near commercial land uses. This explains the mixed land-use patterns that are found in middle-income residential areas. On the other hand, low-income residential areas were observed to be, dominantly, in large homogeneous and continuous patches.
\end{abstract}

Keywords: landscape metrics, social exclusion, spatial mismatch, urban growth

\section{Introduction}

The way urban space is allocated can be used to reinforce inequality. One such example is in apartheid South Africa where the Group Areas Act of 1950 segregated people according to race (Wilkinson, 2000). Post-apartheid cities in South Africa inherited city structures that are characterized by inefficiencies that range from unequal access to economic and social opportunities, peripheral location of low-income households, segregated access to transport and others (Boraine et al., 2006; du Toit, 2007; Maylam, 2009). Cape Town, like most cities in South Africa, is characterized by these spatial inefficiencies (du Plessis \& Landman, 2002). The location of economic activities, relative to residential areas, has resulted in people spending around $43 \%$ of their income on transport, which is above the $10 \%$ benchmark set by the government (South African Government, 1996; TDA, 2017). Public policy has aimed

Copyright 2018 Hazvinei T. Tamuka Moyo \& Mark H. Zuidgeest

http://dx.doi.org/10.5198/jtlu.2018.1061

ISSN: 1938-7849 | Licensed under the Creative Commons Attribution - Noncommercial License 4.0

The Journal of Transport and Land Use is the official journal of the World Society for Transport and Land Use (WSTLUR) and is published and sponsored by the University of Minnesota Center for Transportation Studies. This paper is also published with additional sponsorship from WSTLUR. 
at providing housing and removing racial polarization through mixed-race neighborhoods, especially for the low-income population. However, it has been cited that these policies have exacerbated segregation along economic lines (Turok, 2001). Further, the presence and growth of informal settlements remains a visible feature in the Cape Town urban fabric. This represents unique land-use characteristics and challenges the provision of basic services, such as water and sanitation, transport etc., among others.

The continuous citing of inefficiencies (du Plessis, 2002) calls for restructuring, with regards to transport planning and land-use policies, to redress these issues. Turok (2001) argues that post-apartheid planning ideologies exacerbate persistent polarization in the location of centers of economic activities and provision of public services. Recent debates in land use and transport planning within South Africa have introduced policies that aim at transformation and inclusion (South African Government, 1996, 2009).

One of the key issues included in the Cape Town Spatial Development Framework (Vision 2040), for example, is the integration of land use, economic and transport planning, such that there is access to economic and social activities with the aim of reducing marginalization of low-income earners (City of Cape Town, 2012). However, despite the provision of policy documents as rubrics for desired city structures and "economic articulation", the current spatial patterns suggest that more needs to be done to solve issues of spatial mismatch with regards to residential locations of low-income earners and centers of economic activities.

The preceding discussion frames this research and underscores the need to account for the spatial relationship between residential land uses and economic activities in Cape Town. Therefore, this research seeks to understand the relationship and the growth trajectory of residential, manufacturing and commercial land uses in Cape Town. These findings are then linked to policy development, with the aim of assessing whether policy and land-use planning are aligned. This provides an avenue to better understand the trajectory of land-use change in Cape Town and how this translates to better accessibility to employment, expressed in terms of the spatial location of centers of economic activities relative to residential areas. This discussion then hopes to provoke a dialogue on urban growth and spatial planning policies in areas where, historically, there was marginalization of low-income earners, to redress equality.

The research borrows from spatial ecology by applying spatial metrics to provide a more nuanced understanding of the urban growth trends within the City of Cape Town. Spatial metrics have been applied to understand ecological processes pertaining to the interactions between spatial and temporal patterns of a landscape and its related surroundings. Given that similarities exist in the temporal and spatial dimensions within landscape ecology and spatial planning (Antrop, 2001), this implies that approaches that are used in understanding ecological processes can be implemented within a spatial framework to understand urban processes (Botequilha Leitão, Miller, Ahern, \& McGarigal, 2006; Botequilha Leitão \& Ahern, 2002; Corry \& Iverson, 2005; Kim \& Ellis, 2009; Steinitz et al., 2005) Additionally, spatial metrics techniques have been used to aid in the validation and calibration of urban growth models, following (Herold, Goldstein, \& Clarke, 2003) indicating that spatial metrics can be implemented to enhance our knowledge of urban landscapes. To facilitate the use of spatial metrics, landscape properties were identified that can be quantified using a set of ecological landscape metrics. This provides an opportunity to measure the composition and spatial structure of landscapes. Landscape metrics can be analyzed at a class level, hence, they can be used to understand spatial patterns of individual land uses. Relatedly, for this study, the degree of aggregation, dispersion and clustering of different land uses that mainly serve as trip origins and destinations in Cape Town, are evaluated. This will not only allow for the evaluation of individual land uses but also the relationship between different land uses.

The paper is structured as follows: Section 2 briefly describes the geographical, housing and social context of Cape Town, before discussing the methodological approaches that are implemented. The 
results and discussions of the findings are discussed in Section 3, and Section 4 concludes and discusses policy related outcomes that flow from the study.

\section{Data and methods}

\subsection{Study area}

Cape Town is the second most populous city in South Africa. It occupies $2,240 \mathrm{~km}^{2}$ of the Western Capes geographical space. The Table Mountain range bounds the city in the south-eastern part with chains of mountains running more than $50 \mathrm{~km}$ southwards along the Peninsula (Wilkinson, 2000). The population of Cape Town has increased from 529,000 inhabitants in 1940 (Wilkinson, 2000) to 2,893,247 inhabitants in 2001 and 3,740,026 inhabitants in 2011 (Western Cape Provincial Treasury, 2012). Given the extent of residential informality in Cape Town, the population count could be higher. Informal settlements are a common feature of the urban fabric and present a challenge in the provision of basic services, including proper access to economic activities. Further, new housing for the low-income communities continues to be located in the peripheries (Turok \& Watson, 2001) thus precipitating marginalization of this cohort of individuals.

\subsection{Data, pre-processing and land-use classification}

To carry out the analyses on the spatial location of land uses, four land-use datasets were identified for Cape Town: 1995, 2005, 2010 and 2013. Initially, each of the land-use maps had eighteen land-use types. These were condensed to nine land uses: low-, middle- and high-income residential, informal settlements, commercial and manufacturing services, other urban land uses, non-urban land use and the airport. These land-use categories were concluded to be sufficient to characterize the Cape Town urban landscape. To identify residential areas by income, Census data for 1996, 2005 and 2011 was used (Statistics South Africa, 2014). The 1996 census data was used as a reference point to verify the location of these residential areas, whereas 2011 census data was used as a consistency check of these locations. Given that there was a one year gap between the 1996 census and the first data point (1995), 1996 income levels were assumed to be the same as 1995. The same was assumed for the 2010 data, when 2011 income levels were used. Average wage earnings for South Africa were estimated to be $4 \%$ higher in 2005 compared to 1995 (Burger \& Yu, 2007). This percentage was used to estimate 2005 incomes. Further, in Cape Town, there are suburbs that are historically known as low-, middle- or high-income residential areas. This knowledge was used as a second check of the consistency of the data, especially the 2005 data set. Table 1 shows the land-use types that are used in this study.

Table 1: Land use /Land cover types

\begin{tabular}{|l|l|}
\hline Land use type & Description \\
\hline Informal Settlements & Housing that is on land where people have no legal claim. \\
\hline Low Income Residential & $\begin{array}{l}\text { Residential areas for people per capita monthly income of ZAR00 - ZAR 1000 (1996 } \\
\text { prices). }\end{array}$ \\
\hline Middle Income Residential & $\begin{array}{l}\text { Residential areas for people per capita monthly income of ZAR 2000- ZAR } 4000 \text { (1996 } \\
\text { prices). }\end{array}$ \\
\hline High Income Residential & Residential areas for people with per capita monthly income of ZAR 4001 (1996 prices). \\
\hline Commercial Services & This includes business services, insurance, banks, retail, restaurants etc. \\
\hline Manufacturing Services & This includes industrial areas and other manufacturing. \\
\hline Other Urban Land Uses & $\begin{array}{l}\text { This includes open areas that are vacant and have been designated for urban land uses, } \\
\text { schools, clinics and other urban uses. }\end{array}$ \\
\hline Non-Urban Land Uses & These include nature reserves, forests, natural waters, mining and quarry areas. \\
\hline Airport & This includes the Cape Town International Airport and the Military base. \\
\hline
\end{tabular}


To generate the land-use maps that were used for the study, the land-use maps were rasterized to contain cell sizes of $50 \mathrm{~m} \times 50 \mathrm{~m}$ resolution. This resolution was concluded to be small enough to ensure that land uses were not too aggregated and this allowed for roads to be excluded as stand-alone land uses. The land-use maps used in the study are shown in Figures 1 to 4.

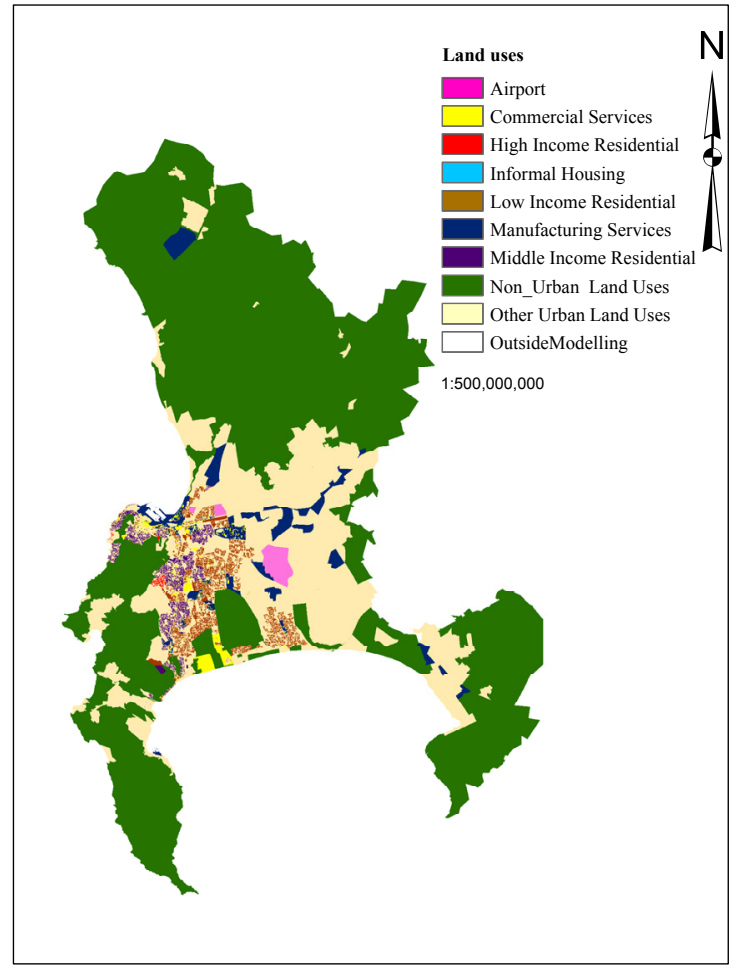

Figure 1: Land use map for Cape Town 1995 


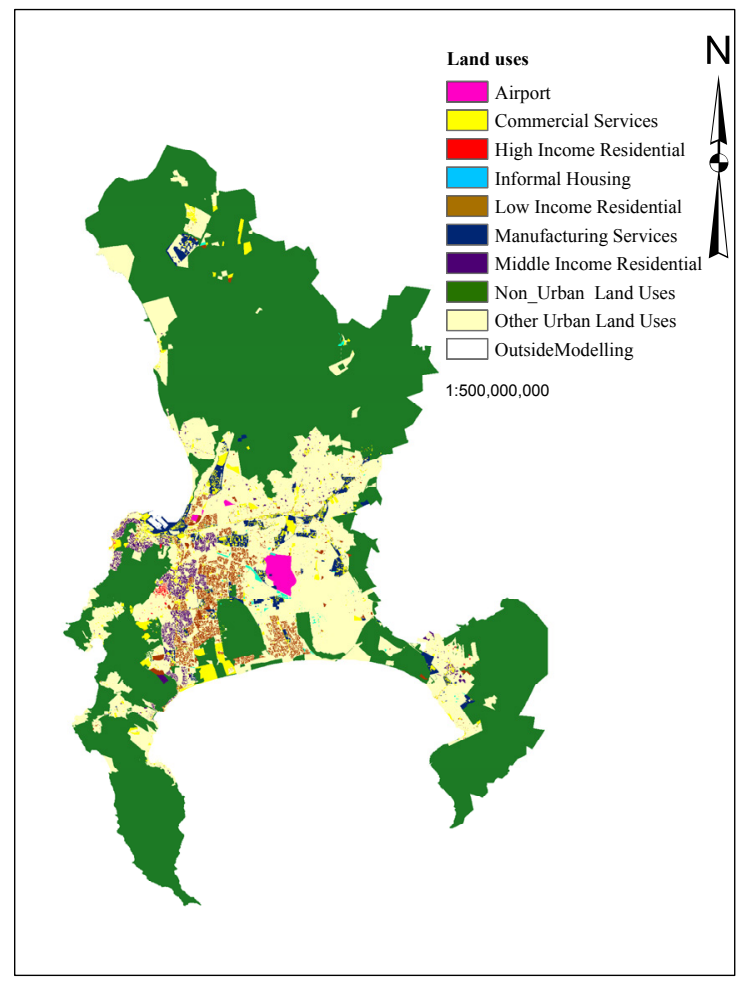

Figure 2: Land use map for Cape Town 2005

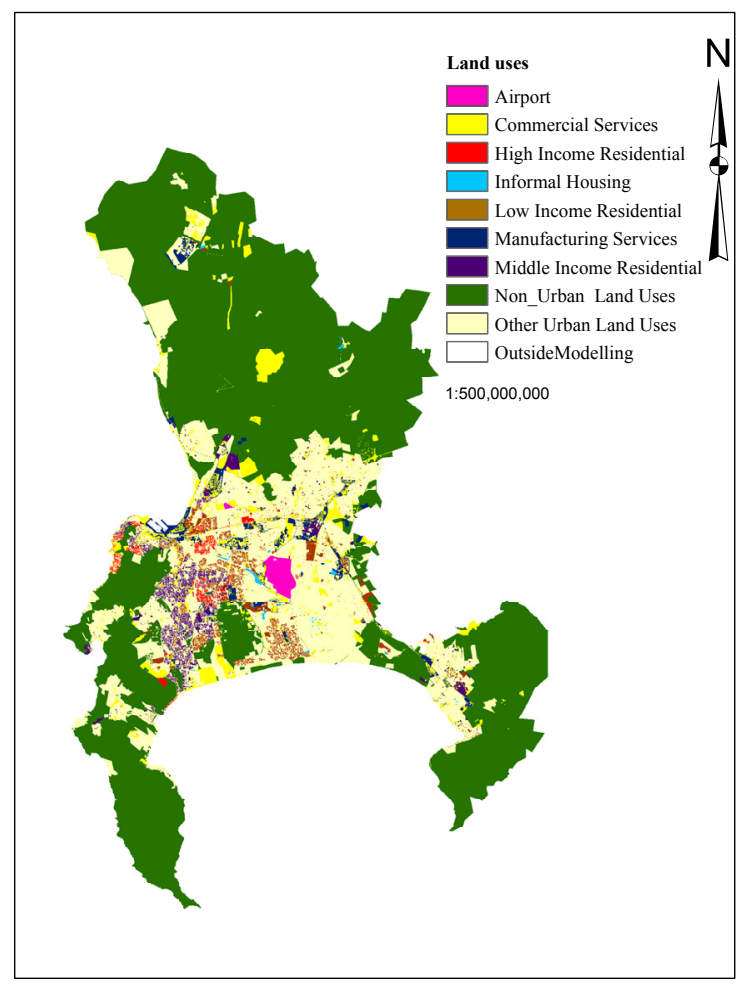

Figure 3: Land use map for Cape Town 2010 


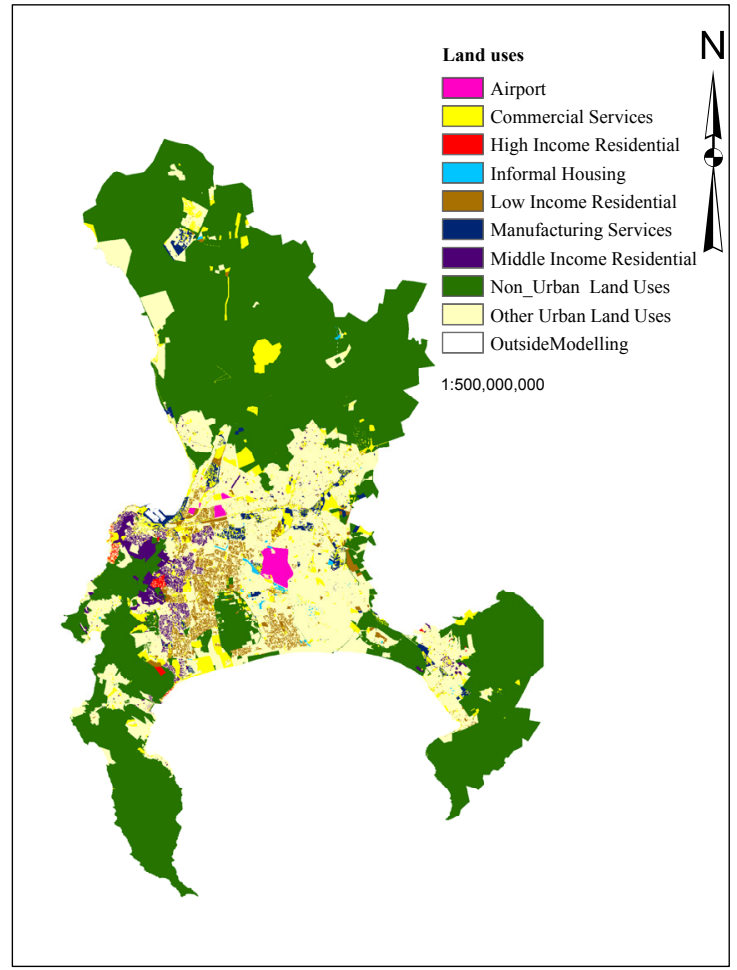

Figure 4: Land use map for Cape Town 2013

\subsection{Methods}

\subsubsection{Understanding the growth of the urban landscape through spatial metrics}

Issues of urban expansion, urban pattern change, and conversion of land uses, urban population growth, social development and economic development, among others, play a large role in the transformation of the urban form. A time series approach is used to understand how the Cape Town landscape has changed over the period 1995-2013. The significance of this period is that it marks the beginning of democracy in South Africa and, subsequently, a move towards more inclusive policy. Within the landuse and transport context, landscape metrics have been applied to understand rural planning (Wu, Kuo, \& Zhang, 2016), urban planning and development (Botequilha Leitão, \& Ahern, 2002), urban sprawl, land-use transition and urban growth (Herold et al., 2003; Herold, Scepan, \& Clarke, 2002; Ji, 2008; Nkeki, 2016; Weng, 2007) and transportation planning (van der Ree, Jaeger, van der Grift, \& Clevenger, 2011), among others.

\subsubsection{Choice of landscape metrics for the study}

The choice of metrics was guided by the characteristic of the landscape that the study aims to measure an approach which has been applied in other studies as well (Haines-Young \& Chopping, 1996; Uuemaa, Antrop, \& Marja, 2009). For this research, topological aspects, such as spatial association, isolation and dispersion, allow for a better analysis of the landscape. Given that, the most appropriate metrics that were chosen include: percentage of land (PLAND), number of patches (NP), Euclidean nearest neighbor-area weighted mean (ENN-AM), proximity index (PI), clumpiness index (CLUMPY), per- 
centage of like adjacencies (PLADJ), interspersion and juxtaposition index (IJI) and aggregation index (AI). Table 2 lists the indices and the aspect of the landscape they explain.

Table 2: Applied landscape metrics

\begin{tabular}{|l|c|c|}
\hline Landscape aspect being measured & Index & Range or Unit \\
\hline Size & Percentage of Land (PLAND) & $\%$ \\
\hline Fragmentation & Number of Patches (NP) & Count \\
\hline Isolation & Nearest Neighbour Distance (ENN) & Metres \\
\hline Isolation & Proximity Index (PI) & Metres \\
\hline Compactness or Dispersion & Clumpiness Index (CLUMPY) & $-1 \leq \mathrm{CLUMPY \leq 1}$ \\
\hline Dispersion & Percentage of Like Adjacencies (PLADJ) & $0 \leq \mathrm{PLADJ} \leq 100$ \\
\hline Dispersion & Interspersion and Juxtaposition Index(IJI) & $0 \leq \mathrm{IJI} \leq 100$ \\
\hline Compactness or Dispersion & Aggregation Index (AI) & $0 \leq \mathrm{AI} \leq 100$ \\
\hline
\end{tabular}

Metrics such as ENN, PI, CLUMPY, AI, IJI and AI allow one to quantify the structural aspects of the landscape as they can be identified as isolation or compaction metrics (McGarigal, Cushman, Neel, \& Ene, 2002). ENN-AM measures the distance between patches which fall into the same land cover type. For the purposes of this study, the area weighted mean is recorded as it allows for assessment of the relative importance of each patch in relation to patch size. This can be used to understand the spatial distribution of patches of the same land-use class in a landscape. High ENN_AM values indicate that patches are far from each other, while low ENN_AM values show that patches are close together (Botequilha Leitão et al., 2006).

The proximity index measures the degree of spatial isolation of patches of the same land-use class. Given how closely related these two indices are, ENN and PI indices will be used in conjunction to understand the degree of isolation of different patches (Botequilha Leitão et al, 2006).

\subsubsection{Land-use analysis}

As indicated previously, the aim of the study is to identify whether the location and growth of employment centers, relative to residential areas, follow a pattern that is attentive to solving issues of social exclusion and transport affordability, hence, addressing spatial mismatch in Cape Town. To allow for this analysis, landscape metrics were calculated in FRAGSTAT (McGarigal et al., 2002). All metrics were operationalized using an 8 cell neighborhood rule. For metrics that required a search radius, a 2,000m search radius was applied.

For this study, commercial and manufacturing areas were identified as trip destinations for individuals, while residential areas where identified as trip origins. Although informal settlements are an integral part of the Cape Town landscape, the discussion is not included in this study. There is uncertainty as to whether all informal settlement locations are accounted for in the data reports by the City of Cape Town. This presents a problem in analyzing their spatial trends ${ }^{1}$.

Hence, the study will focus on commercial, manufacturing, low, middle and high-income residential land-use classes. A pairwise comparison approach was also taken to allow for the analysis of residential land-use patterns relative to commercial and manufacturing sectors. For each of the pairwise comparisons, the residential land-use classes were classified into the same land-use category, with either commercial or manufacturing, while keeping the rest of the land uses constant. For example, to make a comparison between low-income residential and commercial, the two land-use classes were combined into one land-use class: mixed low-income and commercial services, while high- and middle-income residential and manufacturing services were kept as individual land-use classes. For each of the pairwise

${ }^{1}$ Although the discussion does not include informal settlements, the results from the analysis are presented in this research to alert the reader on the presence of informal settlements and their share on the landscape. 
comparisons, proximity index, Euclidean nearest neighbour, percentage of like adjacencies and interspersion and juxtaposition and aggregation index were analysed. The PLAND and NP were used to quantify the individual land-use compositions of the landscape.

\section{$3 \quad$ Results and discussion}

\subsection{Land-use composition}

An analysis of the land cover in Cape Town, using the percentage of land cover (PLAND), shows that the amount of land space occupied by the commercial sector increased from $0.29 \%$ in 1995 to around $2 \%$ in 2013. The manufacturing sector occupies a significant part of the landscape which was around $1.2 \%$ in 1995, however, this fell to around $0.6 \%$ in 2013 due to a decline in productivity (Quantec Research, 2016), which led to the closing down of some manufacturing companies. These locations, in some cases, became brownfields or were converted to other land uses. Further, commercial areas have the largest number of patches $(3,196)$ in 2013 , followed by low-income residential areas $(1,081)$. Figures 5 and 6 present the number of patches and the total space in percentages ${ }^{2}$ that each land use occupies.

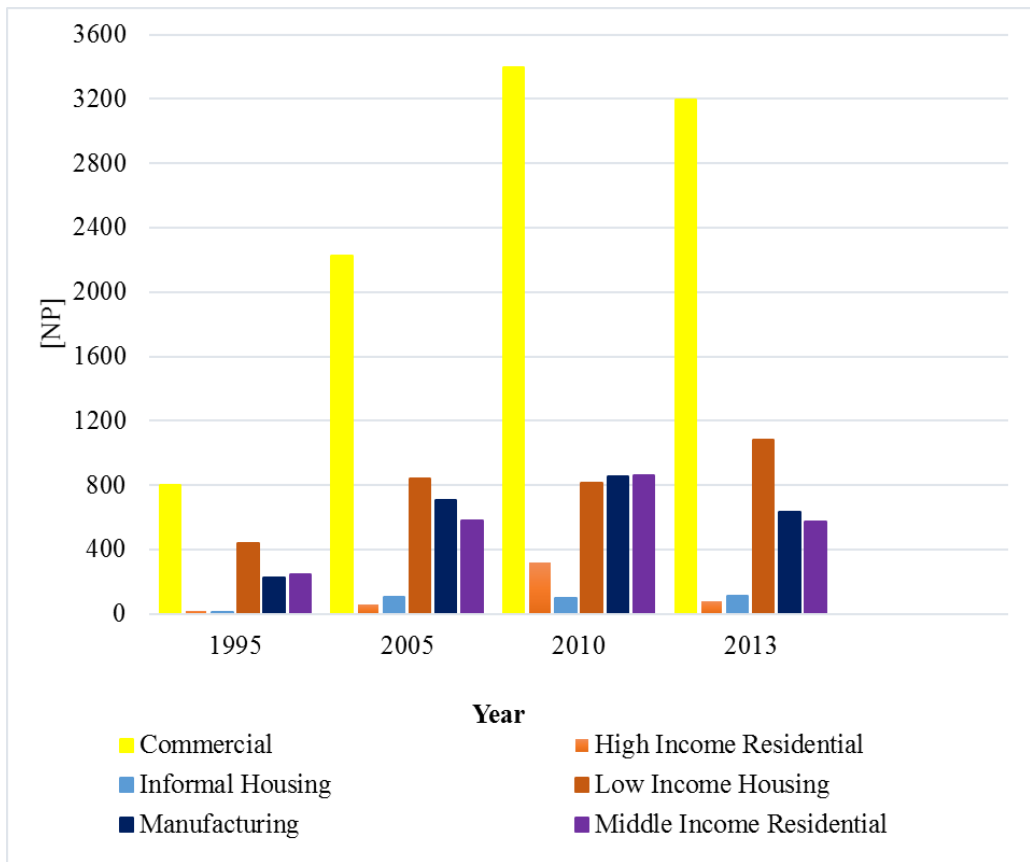

Figure 5: Number of patches [NP] for different land use types

\footnotetext{
${ }^{2}$ Land uses, such as the airport, nature reserves, schools, recreation, etc. are not shown in this figure.
} 


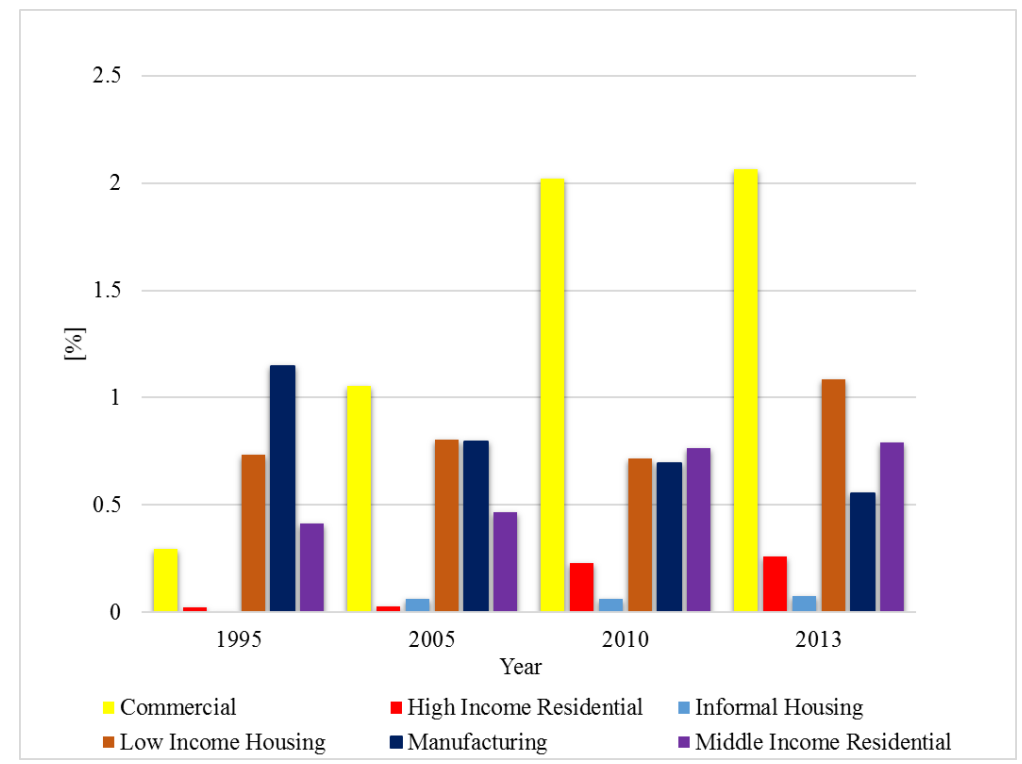

Figure 6: Percentage of land [PLAND] occupied by each land use type

\subsection{Isolation of land-use patches}

To evaluate the distance between patches which fall in the same land-use class, which explains the compactness of the Cape Town Metropolitan region, the ENN, PI, CLUMPY, IJI, PLAND, are reported for the individual land uses and for the pairwise analysis. The Euclidean distance and proximity index are used in conjunction to better explain the degree of isolation of land uses (Botequilha Leitão et al., 2006), especially those falling within the land-use class. For the individual land uses, the area weighted mean ENN (Figure 7) shows that manufacturing services have the largest distance between patches in 1995 and the number significantly drops for the rest of the study period. This significant drop in the distance between patches could be linked to the closing of companies, especially in the textile manufacturing sector, due to competition from cheap imports. The proximity index (Figure 8) supports this finding, as seen by the low values in the index for manufacturing patches, suggesting that the remaining land-use patches are within the same manufacturing sector, hence, most likely located close together. Further, low-income residential areas consistently have short distances between patches, indicating that this land use is growing in large patches. Relatedly, as the low-income residential patches increased, they also tend to cluster together, thus, resulting in large compact low-income patches. This shows that new low-income residential areas are situated in close proximity to already existing low-income residential areas. Overall, the growth of low-income residential shown in Figures 7 and 8 are consistent with the genesis of the low-income residential neighborhoods and the subsequent exurban location of new lowincome housing.

Similarly, middle-income residential areas have consistently shown low average distances (low ENN-AM values) between patches over the study period which suggests that new middle-income patches over the period have generally located close to already existing middle-income areas. However, a slight increase in the distance between patches has also been observed (Figure 8) between 2005 and 2010. 


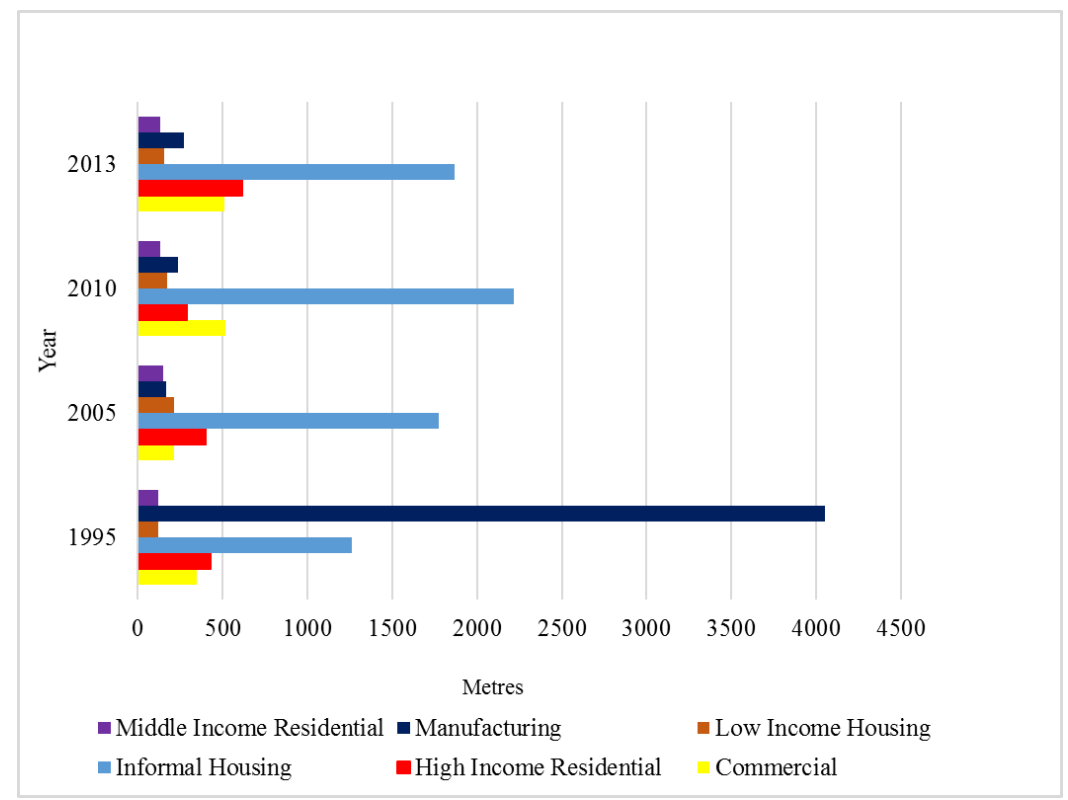

Figure 7: Distance between land use patches (Euclidean nearest neighbour area weighted mean)

What this result suggests is that new medium-income residential areas may be located a little further from other medium residential areas. This could be explained by a possible proliferation of other land uses close to middle-income areas, indicating mixed land uses. This finding is further explored using pairwise comparisons of medium residential and commercial land uses in Section 3.4, Figures 13 and 14. High-income residential areas were also observed to be close to other high-income residential areas (Figures 7 and 8). This pattern indicates the preference by high-income home owners to locate close to other high-income residential areas.

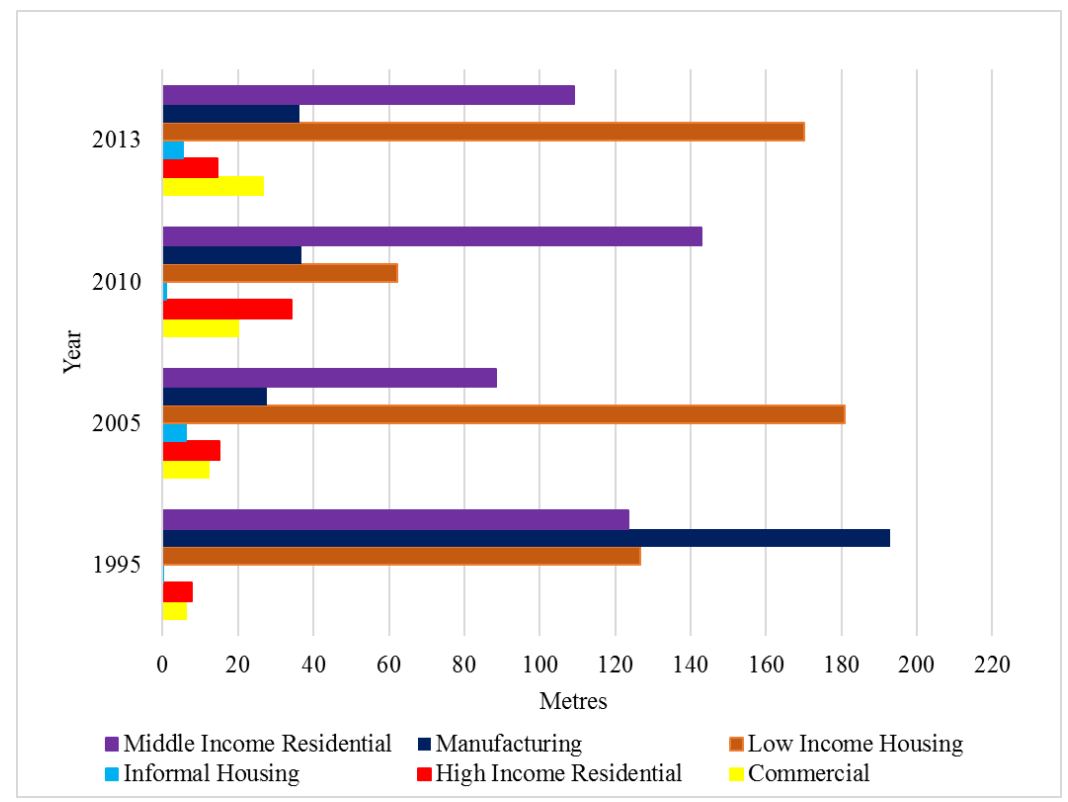

Figure 8: Proximity Index area weight mean of individual land uses (PI-AM) 


\subsection{Urban sprawl in Cape Town}

Urban sprawl leads to urban spatial patterns that are fragmented (Poelmans \& Rompaey, 2009). The costs and impacts associated with dispersed urban development have been cited with in particular reference to their inefficient nature and the impact on accessibility to key activities, such as jobs, schools, hospitals and others (Ewing \& Cervero, 2010). In Cape Town, urban sprawl and low urban densities are at the core of the discussion on urban inefficiencies, especially its influence on efficient public transport provision (Palmer, Brown-Luthango, \& Berrisford, 2011). Spatial metrics for urban sprawl typically include metrics that evaluate patchiness, dispersions and interspersion of land uses, and have been used here. To measure urban sprawl, this study uses the clumpiness index which evaluates the spatial compactness of urban land uses. The index ranges from -1 to 1 where 1 indicates that land uses are aggregated and -1 shows disaggregation (Kew \& Lee, 2013). If the difference in clumpiness between different years is positive, this may be indicative of land uses becoming more compact (van Delden $\&$ van Vliet, 2008).

The results from analyzing the clumpiness of land uses (Figure 9) indicate that all land uses have relatively high clumpiness values. This indicates that land uses within the same land-use class are found near each other. This suggests that for most land-use classes, there are large continuous patches which may make it difficult for other land uses to appear close to them. This encourages outward growth of land uses, hence, limited opportunity for infilling and mixing of land uses. Middle-income patches have become relatively more compact compared to any other land use, as shown by the increase in the clumpiness value from 0.59 to 0.73 in the period 1995 to 2013. However, a comparison between 1995 and 2005 shows a $3.81 \%$ percent decrease in the clumpiness index. Though the value is relatively small, this outcome suggests that there may be other land-use classes that emerged or that the middle-income residential areas were converted into other land use. Given that residential land uses tend to persist in their original locations, an emergence of new land uses, close to middle-income areas, is a more plausible explanation for a change in the index.

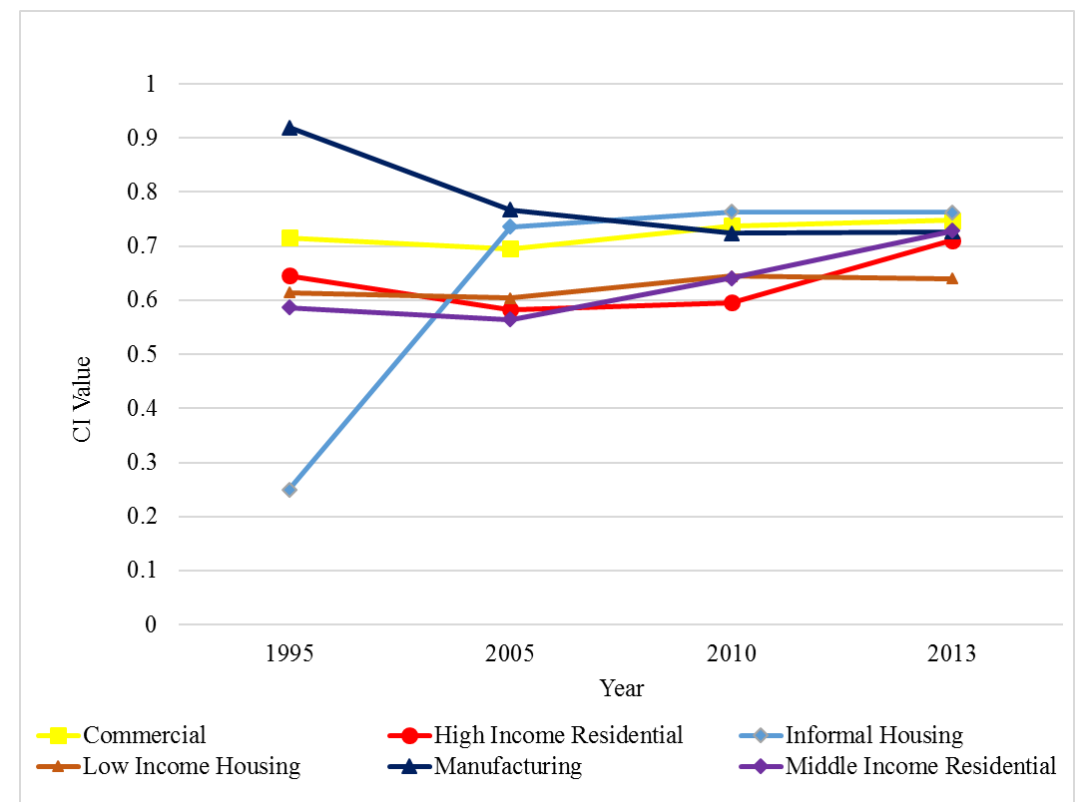

Figure 9: Sprawl measure (Clumpiness index)

Clumpiness values for low-income residential areas have significantly increased from 1995 to 2005 
and, from thereon, they have become constant. The increase in the clumpiness values indicates that low-income land uses are becoming more compact, implying large patches close to already existing low-income patches. Given the historical location of low-income residential areas, the growth in these patches is most likely to happen towards the urban fringe, hence, perpetuating previous low-income spatial patterns. This growth trajectory emboldens single land uses and the eventual sprawling of lowincome residential areas away from centers of economic activities.

\subsection{Compactness and the potential of mixed land uses}

More insight into the degree of compactness and potential mixing of land uses is attained by evaluating the occurrence of similar land uses adjacent to each other. This is done by evaluating the percentage of like adjacencies (PLADJ). The advantage of using the PLADJ as an assessment measure is that it allows for the evaluation of dispersion or mixing of land-use classes. Figure 10 summarizes these findings.

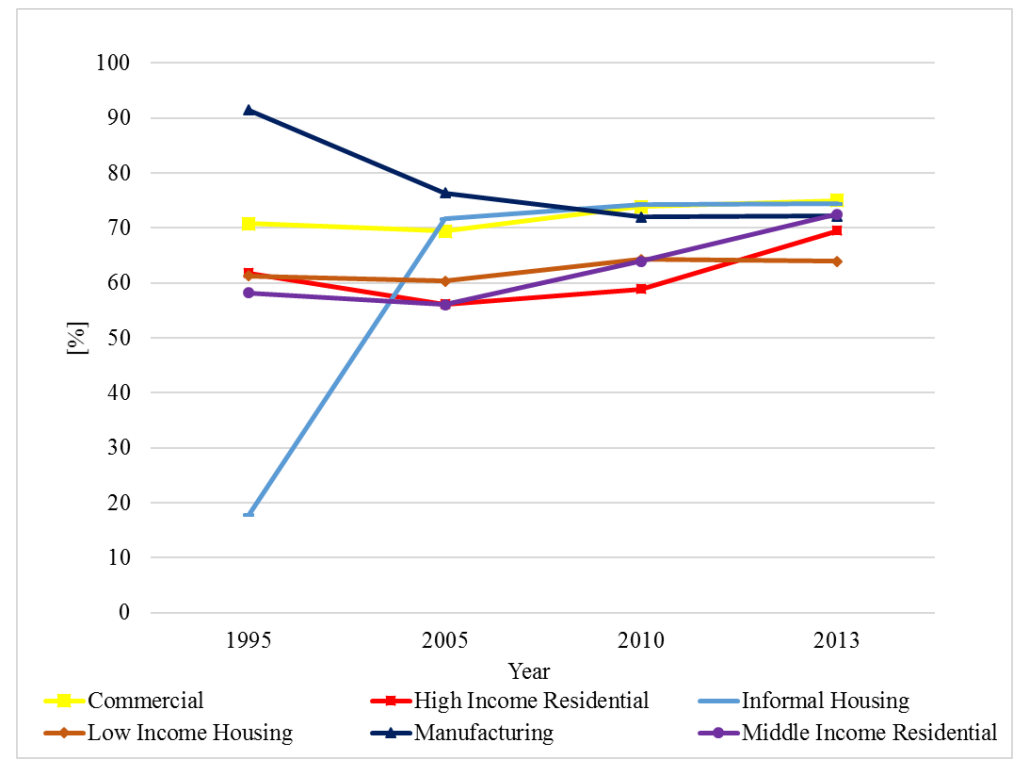

Figure 10: Percentage of like adjacencies for individual land uses

Commercial and manufacturing services have the highest PLADJ values in 1995. For manufacturing, there is a noticeable decline between 1995 and 2013. As mentioned earlier, the manufacturing sector experienced a decline in production and subsequent closure of some companies, which may account for the change in the index. For middle- and high-income residential areas, the like adjacency values decrease between 1995 and 2005 and then increase for the remainder of the study period. The PLADJ for low-income residential increases by about 3\% between 1995 to 2013. This is consistent with the findings from the clumpiness index, which revealed that this land use was growing into large continuous patches.

Further, the application of the interspersion and juxtaposition index (IJI) in this study also brought in a new dimension which aided in better understanding the distribution of land uses across the landscape (Botequilha Leitão et al., 2006). High interspersion values indicate that land-use patches are evenly distributed across the landscape. Figure 11 below presents the interspersion results. 


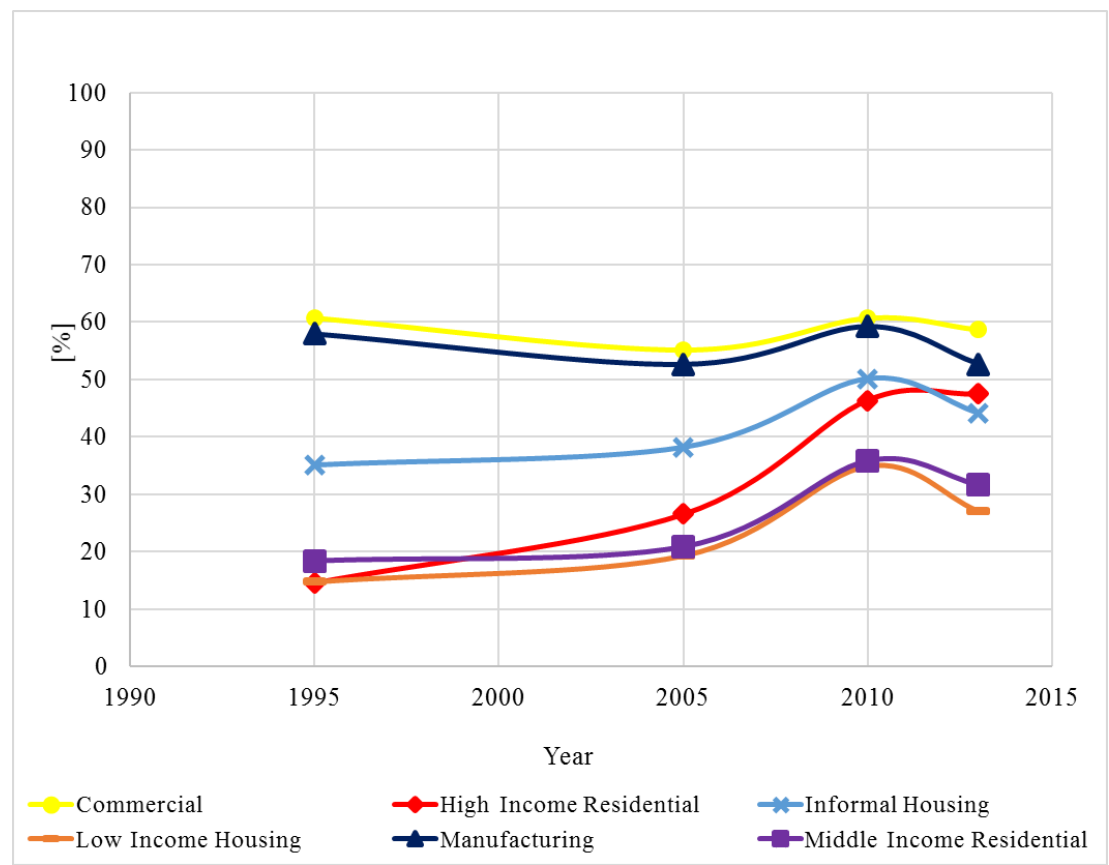

Figure 11: Interspersion index for individual land uses

The interspersion values for all land uses are relatively low for the study period with the highest values being for commercial in 1995 and low-income residential reporting the lowest values. Manufacturing and commercial service values fluctuate over the period. The high-income residential category shows an increase in the interspersion percentage from around 15\% in 1995 to $47 \%$ in 2013, which is the highest change across all land-use classes. Given that the interspersion values for most land uses are below $50 \%$ for the whole period, this indicates that land uses are not evenly distributed across the landscape.

Relatedly, the low interspersion value also suggests that middle and high-income residential are, to some extent, disaggregated. For middle-income residential areas, this can be linked to the decrease in the clumpiness index (Figure 9) between 1995 and 2005 which allowed for the emergence of new land-use types between middle-income patches. This characteristic allows for the development of mixed land uses in areas close to high- and middle-income residential areas. This supports the notion of suburbanization of employment to the high- and middle-income residential areas (Naude, 2008; Turok, 2011). Further, the growth of middle-income estates with apartment buildings in Cape Town, which are characterized by mixed land uses, supports this finding.

The extent to which patches of the same land-use type are aggregated was evaluated using the aggregation index. AI approaches 100 when patches are aggregated, such that they become a single compact patch (Botequilha Leitão et al., 2006; Ramachandra, Aithal, \& Durgappa, 2012.; Ramachandra, Aithal, $\&$ Sreekantha, 2012). The results show that for all land uses, there are high levels of aggregation with most land uses having very large compact patches. This finding supports previous findings in Section 3.2 on the clustered growth of most land uses. Figure 12 shows the AI values for all the land uses. 


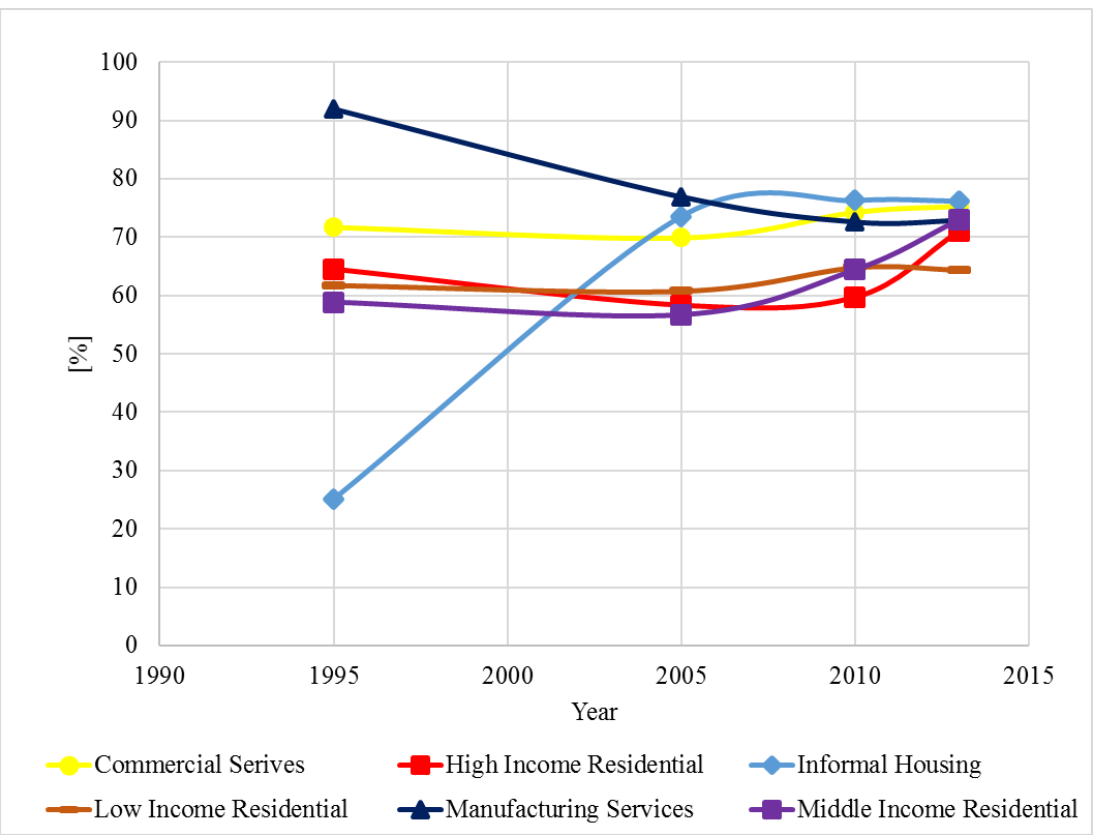

Figure 12: Aggregation index for all land uses

\subsection{Potential for mixed land uses}

The preceding section began a discussion on the possibility of suburbanization of employment. This notion is further explored by carrying out a pairwise comparison of land uses. This analysis ties together the discussion by focusing on the pairwise comparison of residential and commercial or manufacturing land-use classes. The approach taken was to operationalise the same landscape metrics that were used for indvidual land uses to carry out a pairwise comparison of residential land uses with either manufacturing or commercial land uses. Figures 13 through to 17 report on the findings from the pairwise analyses.

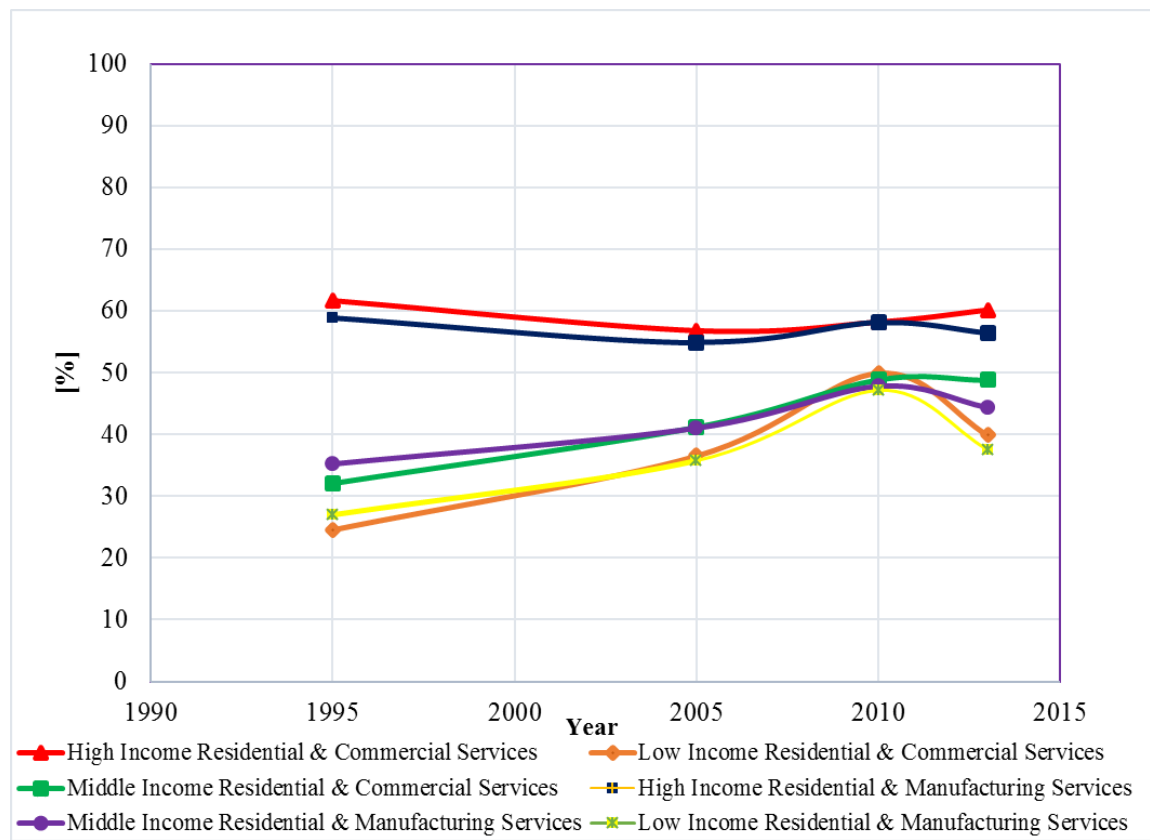

Figure 13: Interspersion and juxtaposition index for combined land uses 


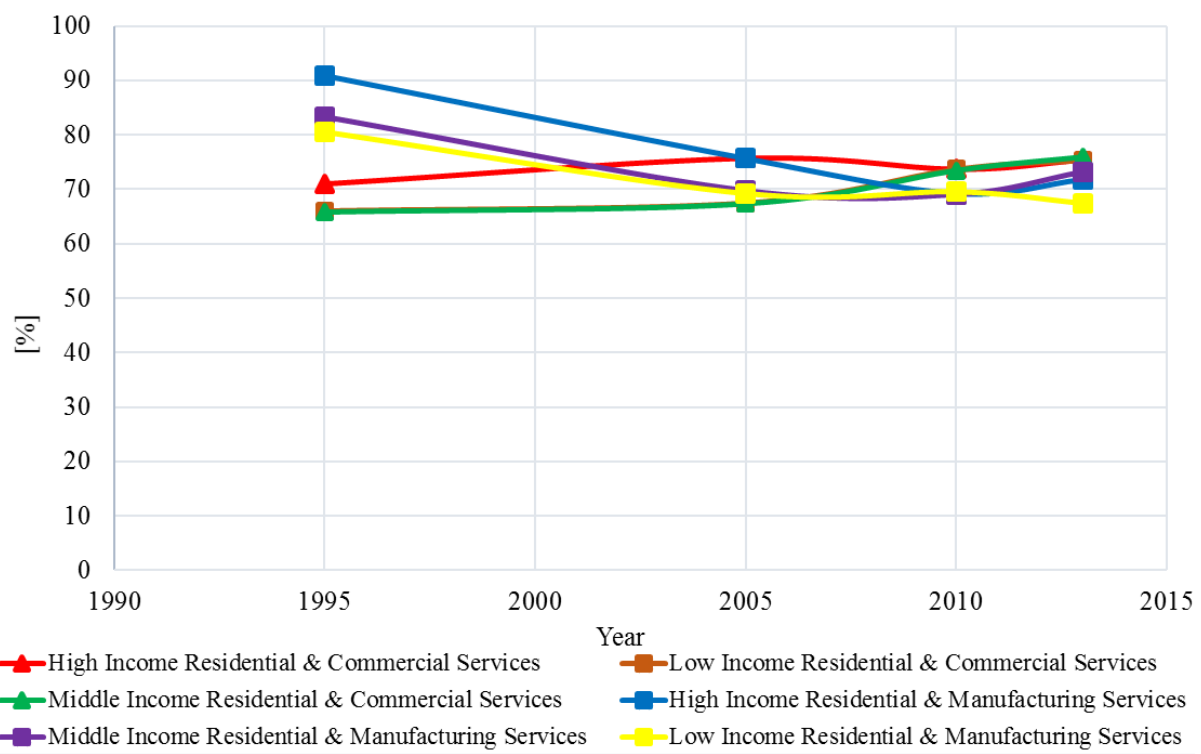

Figure 14: Aggregation index for combined land uses

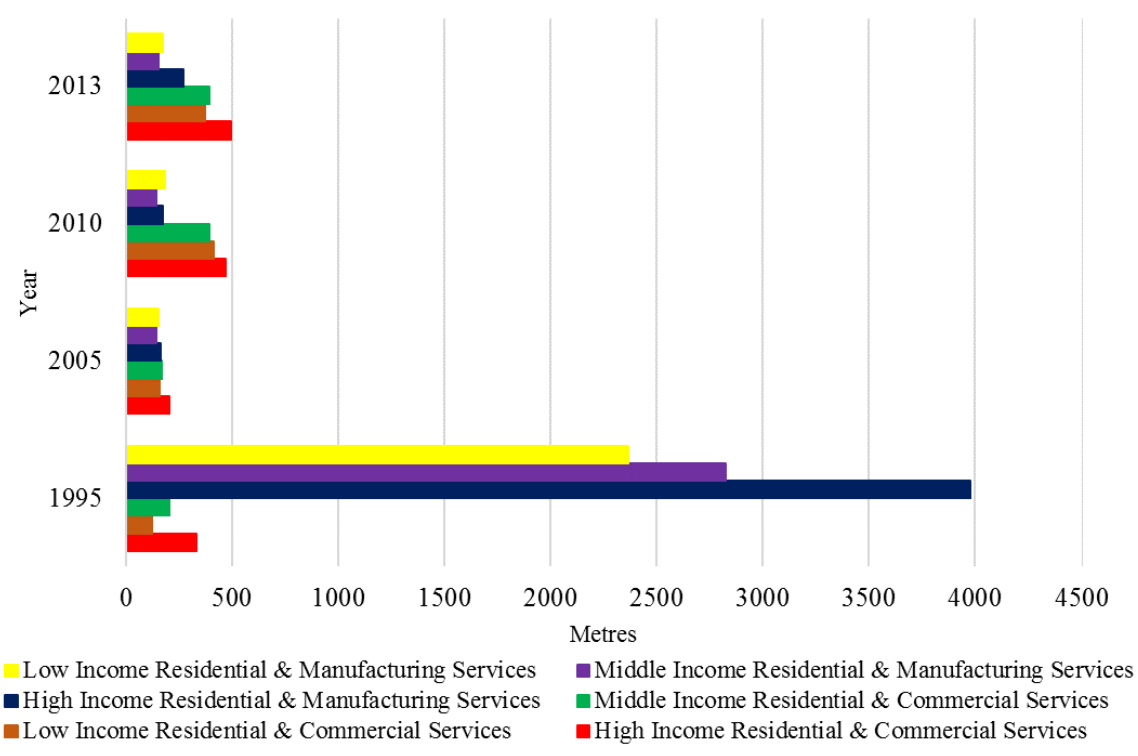

Figure 15: Distance between selected land uses (Euclidean nearest neighbour) 


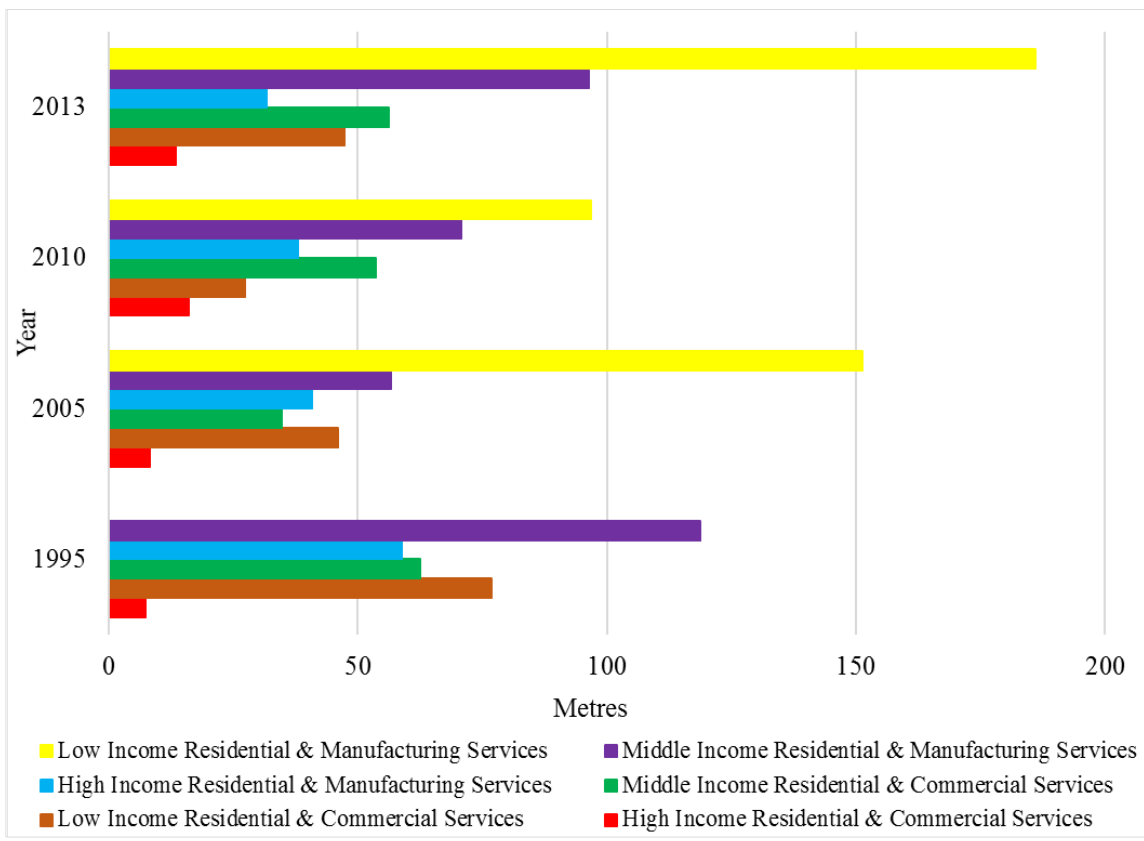

Figure 16: Proximity index for combined land uses

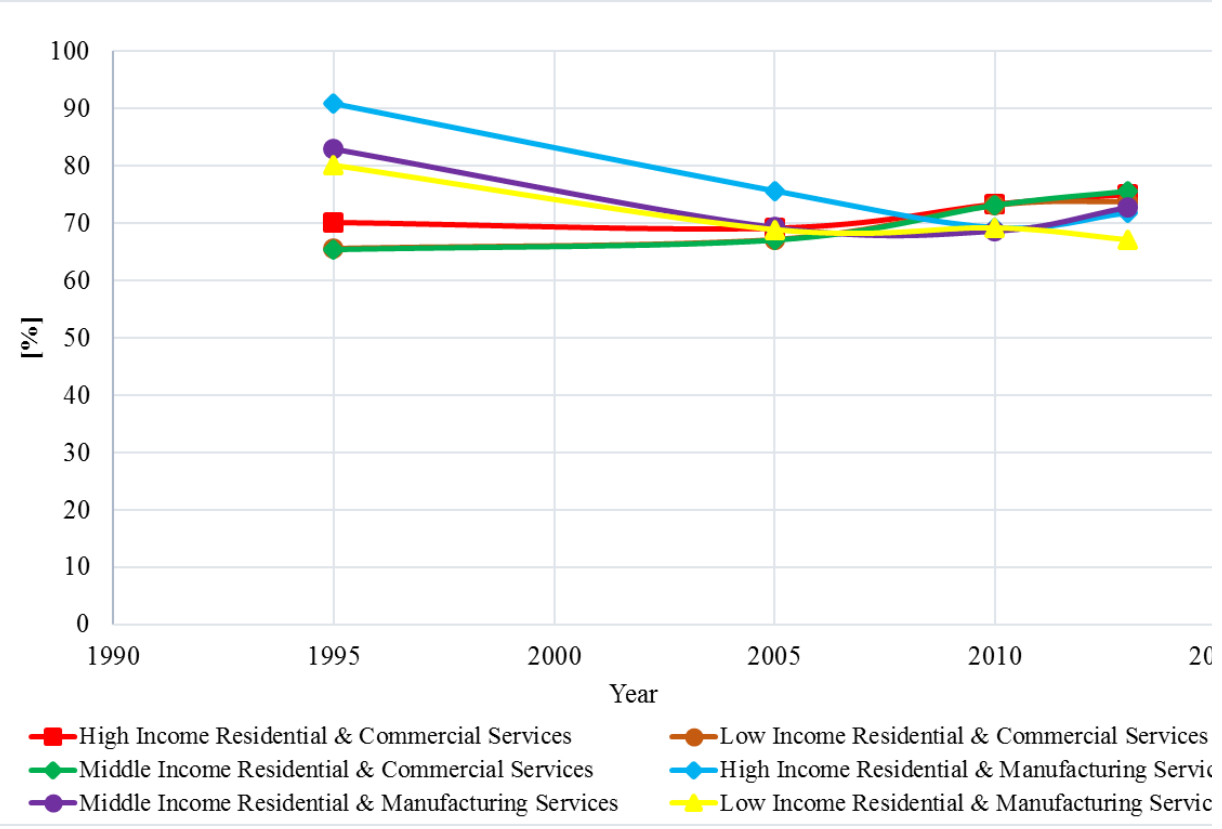

Figure 17: Percentage of like adjacencies for combined land uses

The results from this analysis show higher interspersion values for high-income residential combined with commercial land uses, hence, showing aggregation. This can be construed to indicate that high income and commercial services are found near each other, hence, the presence of mixed land uses. Low income combined with commercial services shows low interspersion values, revealing that these land uses are not in close proximity across the metropolitan area. However, these values have increased 
over the period with a total positive change of around 25\% between 1995 and 2005 for low-income residential and commercial and a change of around $11 \%$ for low-income residential and manufacturing. These findings suggest that vacant land between low-income residential provide an opportunity for infilling by other land uses. Given the present policy in Cape Town, it is possible that commercial and manufacturing land uses are found in these areas, thus, possible mixed land uses. This can be corroborated by findings from other studies (du Plessis, 2015).

The observed results for all pairwise comparisons show that the index for compactness, aggregation index (AI), has remained relatively high over the period. For the relationship between high and middleincome residential areas, combined with manufacturing services, the AI has decreased which is not an unusual observation. For high and middle-income land uses, combined with commercial land use, the AI has increased for the same period and this is characteristic of the growth trends in these land uses in Cape Town. The aggregation for low income combined with commercial has also increased, even though this has been very low over the period. What these findings suggest is that low-income residential and commercial land uses are not, generally, found close to each other. An explanation that could help in understanding this trend is the need for high skilled labor for this sector. This has also been identified as a potential cause of the mismatch between the Commercial services and the low-- residential (Turok \& Watson, 2001). Further, the education trends in these low-income neighborhoods (STATSSA, 2012) resonate with low skills, hence, it is plausible for only a few commercial sector patches to locate in these areas. In that regard, this would perpetuate the spatial mismatch between low-income residential and commercial services sector job locations.

The ENN analyses show that for all land uses the distances range between 145 meters to 264 meters. The distance for high-income residential combined with commercial has decreased over the years, while for low income combined with commercial the distance has increased. The middle income combined with either commercial or manufacturing analysis shows that the distance has fluctuated over the years. The high-income residential paired with commercial and manufacturing relationship shows a decrease in the average ENN distances.

Employing Euclidean distance alone as a measure of understanding the distance between land uses in a landscape does not fully report the general structure of the landscape, as such, the proximity index findings are also reported. Low-income residential combined with manufacturing has the largest distances. However, this has reduced over the study period. The distances for middle-income and highincome residential combined with commercial have remained relatively low over the period. For highincome residential combined with manufacturing the distances have reduced over the period. These distances have been considerably low from the beginning of the period of assessment. One can interpret this as a possible mixing of these land uses.

\section{Conclusions}

By using spatial metrics, we have managed to evaluate the spatial structure and location of land uses in the Cape Town metropolitan area. Special attention was given to residential, commercial and manufacturing land uses which serve as trip origins and destinations. The results revealed that there was a significant drop in the share of manufacturing land use and this was attributed to a reduction in productivity in this sector. High clumpiness index values for individual land uses were observed, indicating that most land uses are growing into single large patches. This result suggests that the growth trajectory of residential land uses is biased towards large compact individual land-use patches.

Relatedly, the pairwise comparison showed that high- and middle-income residential areas are closer to commercial and manufacturing land uses, as compared to low-income residential land uses. This is a worrying pattern especially for the low-income residential areas which are already located in the pe- 
ripheries, as any outward growth implies a sprawl of the city with low-income residential areas continuously segregated from key centers of employment. A continuation of this growth trajectory perpetuates pre-1994 planning characteristics, as observed by other studies (Turok \& Parnell, 2009; Turok, 2001)

This result also suggests a bias in the location of commercial land uses in prominent neighborhoods indicating that middle- and high-income cohorts have better accessibility to employment destinations compared to low-income residential areas. This was revealed in the high percentage like adjacencies (Figure 14) for the middle and high income compared with commercial land uses. A decrease in the average distances for low income paired with manufacturing indicates that either some manufacturing companies have located close to low-income residential areas or vice versa. This is an encouraging finding and points to efforts in policy to increase accessibility for the low-income cohort.

The study appreciates efforts being made to provide housing for low-income earners, still, the model that is being applied with regards to the location of these residential areas needs to be re-evaluated. The results have revealed that the current planning trends are perpetuating apartheid spatial structures, which not only increase the transport subsidy bill but also exacerbates the social and economic gap between income groups. The redevelopment of brownfields and infilling of open spaces, close to economic centers with low-income residential housing, is a step towards filling the inequality and social exclusion gap. Relatedly, incentives such as the Urban Development Zone (UDZ) are a step in the right direction, but the question remains whether there are sufficient incentives to encourage private stakeholders to invest in the construction of low-income housing in the UDZ.

There is a need to evaluate the missing linkages within the planning context to identify aspects that perpetuate the current spatial trends. The government continues to build housing for low-income earners in the outskirts (Figures 6 and 7 revealed this trend) of the city under the reconstruction and development program (RDP), thus, there is no incentive for private low-income property developers to locate in these UDZs, which are relatively more expensive compared to the outskirts.

In that regard, the government needs to set an example by taking the risk and potential loss in profit and construct low-income housing in these urban development zones if there are indeed "benefits" for the developers. This is one strategy that can be employed if they are to set the tone on the level of commitment to redress some of the disparities due to past planning policies.

In a context where the spatial dimension of land-use location is driven by market forces that seek economic gain, it is difficult to incorporate the needs of the disadvantaged without jeopardizing market performance. Nonetheless, the government can play a part in incentivizing the private sector, especially those in low skills sectors, so that they locate closer to low-income residential areas. If companies find it attractive to locate in middle and high-income residential areas, low-income residential areas can also be developed such that they attract employment.

From a policy standpoint, more needs to be done to ensure that, in the next 20 years, a similar analysis would reveal a visible change in the planning ideology seen through the spatial configuration of the urban landscape that shows a more inclusive and transformative urban form. Finally, given that the overall results show a persistence in apartheid spatial structures, further work is needed to examine the spatial location of health services and schools, to evaluate whether there are changes in access to these services for the low-income residential areas. This may provide an explanation for the slow progress observed with regards to the location of low-income residential areas relative to economic centers. The present research excluded informal settlements from the discussion, due to lack of sufficient data in the reporting of informal settlements and their locations, even though they are resident to a significant share of low-income earners. Further research should consider discussions around accessibility for informal settlement dwellers and how this can be translated to better transport and service access to this cohort of individuals. 


\section{Acknowledgements}

The authors would like to thank the National Research Foundation (NRF) of South Africa and the Carnegie Corporation of New York for funding this research. 


\section{References}

Antrop, M. (2001). The language of landscape ecologists and planners: A comparative content analysis of concepts used in landscape ecology. Landscape and Urban Planning, 55, 163-173. Retrieved from http://s3.amazonaws.com/academia.edu.documents/42316032/1-s2.0-S0169204601001517-main. pdf?AWSAccessKeyId=AKIAJ56TQJRTWSMTNPEA\&Expires $=1477778252 \&$ Signature $=Z i 910$ 2xz7fPFZw34aU4H1d9/oI0=\&response-content-disposition=inline;filename=The_language_of_ landscape

Boraine, A., Crankshaw, O., Engelbrecht, C., Gotz, G., Mbanga, S., Narsoo, M., \& Parnell, S. (2006). The state of South African cities a decade after democracy. Urban Studies, 43(2), 259-284. Retrieved from http://usj.sagepub.com/content/43/2/259.full.pdf+html

Botequilha Leitão, A., \& Ahern, J. (2002). Applying landscape ecological concepts and metrics in sustainable landscape planning. Landscape and Urban Planning, 59, 65-93. Retrieved from http:// s3.amazonaws.com/academia.edu.documents/35533401/LUP02_Botequilha_Leitao_and_Ahern. pdf?AWSAccessKeyId=AKIAJ56TQJRTWSMTNPEA\&Expires $=1477779336 \&$ Signature $=$ RX7C CMWxUTX7JMpzWcqaI3kKOC0=\&response-content-disposition=inline; filename=Applying landscape_ec

Botequilha Leitão, A., Miller, J., Ahern, J., \& McGarigal, K. (2006). Measuring landscapes: A planner's handbook. Washington, DC: Island Press. Retrieved from ftp://46.101.84.92/pdf40/measuringlandscapes-a-planner-s-handbook.pdf

Burger, R., \& Yu, D. (2007). Wage trends in post-apartheid South Africa: Constructing an earnings series from household survey data. SSRN Electronic Journal. doi.org/10.2139/ssrn.966118

City of Cape Town. (2012). Spatial development framework. Cape Town: City of Cape TownSpace. Retrieved from http://resource.capetown.gov.za/documentcentre/Documents/City research reports and review/SDF_Technical_Report_2012_Interactive.pdf

Corry, R. C., \& Iverson, J. (2005). Limitations of using landscape pattern indices to evaluate the ecological consequences of alternative plans and designs. Landscape and Urban Planning, 72, 265-280. doi.org/10.1016/j.landurbplan.2004.04.003

du Plessis, C., \& Landman, K. (2002). Sustainable Analysis of Human Settlements in South Africa. Department of Housing. Retrieved from http://www.repository.up.ac.za/bitstream/handle/2263/14733/ DuToit_Is(2007).pdf?sequence $=1$

du Plessis, D. J. (2015). Land-use mix in South African cities and the influence of spatial planning: Innovation or following the trend ? South African Geographical Journal, 97(3), 217-242. doi.org/10.1 080/03736245.2014.924870

du Toit, J. (2007). Is spatial integration socially sustainable? Town and Regional Planning, 51, 37-45.

Ewing, R., \& Cervero, R. (2010). Travel and the built environment. Journal of the American Planning Association, 76(3), 265-294. doi.org/10.1080/01944361003766766

Haines-Young, R., \& Chopping, M. (1996). Quantifying landscape structure: A review of landscape indices and their application to forested landscapes. Progress in Physical Geography, 20(4), 418-445. Retrieved from http://ppg.sagepub.com/content/20/4/418.full.pdf+html

Herold, M., Goldstein, N. C., \& Clarke, K. C. (2003). The spatiotemporal form of urban growth: Measurement, analysis and modeling. Remote Sensing of Environments, 86, 286-302. doi.org/10.1016/ S0034-4257(03)00075-0

Herold, M., Scepan, J., \& Clarke, K. C. (2002). The use of remote sensing and landscape metrics to describe structures and changes in urban land uses. Environment and Planning A, 34, 1443-1458. doi.org/10.1068/a3496 
Ji, W. (2008). Landscape effects of urban sprawl: Spatial and temporal analysis. The International Archives of Photogrammetry, Remote Sensing and Spatial Information Sciences, 37, 1691-1694.

Kew, B., \& Lee, B. (2013). Measuring sprawl across the urban rural continuum using an amalgamated sprawl index. Sustainability, 5(12), 1806-1828. doi.org/10.3390/su5051806

Kim, J., \& Ellis, C. D. (2009). Landscape and urban planning determining the effects of local development regulations on landscape structure: Comparison of the woodlands and north Houston, TX. Landscape and Urban Planning, 92, 293-303. doi.org/10.1016/j.landurbplan.2009.05.013

Maylam, P. (2009). Explaining the apartheid city: 20 Years of South African urban historiography. Journal of Southern African Studies, 21(1), 19-38. Retrieved from http://abahlali.org/files/ maylam.20yearson.pdf

McGarigal, K., Cushman, S., Neel, M., \& Ene, E. (2002). Fragstats: Spatial pattern analysis program for categorical maps. Retrieved from https://www.umass.edu/landeco/research/fragstats/fragstats.html

Naude, W. (2008). Is there a spatial mismatch in South Africa's metropolitan labor market? Cities, 25, 268-276.

Nkeki, F. N. (2016). Remote sensing applications: Society and environment spatio-temporal analysis of land use transition and urban growth characterization in Benin metropolitan region, Nigeria. Remote Sensing Applications: Society and Environment, 4, 119-137. doi.org/10.1016/j.rsase.2016.08.002

Palmer, I., Brown-Luthango, M., Berrisford, S. (2011, March). The economic and fiscal costs of inefficient land-use patterns in South Africa. Washington, DC: Financial and Fiscal Commision, World Bank Group.

Poelmans, L., \& Rompaey, A. V. (2009). Landscape and urban planning detecting and modelling spatial patterns of urban sprawl in highly fragmented areas: A case study in the Flanders-Brussels region. Landscape and Urban Planning, 93(1), 10-19. doi.org/10.1016/j.landurbplan.2009.05.018

Quantec. (2016, October 12). EasyData [Data file]. Retrieved from http://www.quantec.co.za/

Ramachandra, T., Aithal, B., \& Durgappa, S., D. (2012). Insights to urban dynamics through landscape spatial pattern analysis. International Journal of Applied Earth Observation and Geoinformation, 18, 329-343. doi.org/10.1016/j.jag.2012.03.005

Ramachandra, T., Aithal, B. H., \& Sreekantha, S. (2012). Spatial-metrics based landscape structure and dynamics assessment for an emerging Indian megalopolis. International Journal of Advanced Research in Artificial Intelligence, 1(1), 48. Retrieved from https://www.google.co.za/url?sa=t\&rct=j\&q=\&esr $\mathrm{c}=s \&$ source $=$ web\&cd=1\&cad=rja\&uact=8\&ved=0ahUKEwiO6v_jkIHQAhVTGsAKHZ1VCyU QFggfMAA\&url=http://citeseerx.ist.psu.edu/viewdoc/download?doi=10.1.1.259.568\&rep=rep1\& type=pdf\&usg=AFQjCNHfKTLdaWKJ0-Cn2H3CYVI1datvSQ\&sig

South African Government. (1996). White paper on national transport policy. Cape Town: South African Government, Department of Transport. Retrieved from https://www.comair.co.za/Media/Comair/ files/level-playing-field/White-Paper-on-Nat-Transport-Policy-1996.pdf

South African Government. (2009). Government Gazette (Vol. 52). Cape Town: South African Government. Retrieved from http://www.transport.gov.za/Portals/0/PublicTransport/nptr/docs/NLTA_ Act_2009_june2016.pdf

Statistics South Africa. (2014). NHTS provincial report Western Cape profile. Cape Town: Statistics South Africa.

STATSSA. (2012). Statistical release (revised) Census 2011. Pretoria. doi.org/P0301.4

Steinitz, C., Anderson, R., Arias, H., Bassett, S., Flaxman, M., Goode, T., Maddock, T., Mouat, D., Peiser, R., \& Shearer, A. (2005). Alternative futures for landscapes in the Upper San Pedro River basin of Arizona and Sonora. Retrieved from https://www.researchgate.net/publication/228506635_Alternative_Futures_for_Landscapes_in_the_Upper_San_Pedro_River_Basin_of_Arizona_and_Sonora 
TDA. (2017). Draft Cape Town municipal spatial development framework (MSDF) 2017-2022. Cape Town: The City of Cape Town's Transport and Urban Development Authority, City of Cape Town. Turok, I. (2001). Persistent polarization post-apartheid ? Progress toward urban integration in Cape Town. Urban Studies, 38(13), 2349-2377. Retrieved from https://doi.org/10.1080/00420980120094551

Turok, I. (2011). Deconstructing density: Strategic dilemmas confronting the post-apartheid city. Cities, 28(5), 470-477. Retrieved from https://doi.org/10.1016/j.cities.2010.10.003

Turok, I., \& Parnell, S. (2009). Reshaping cities, rebuilding nations: The role of national urban policies. Urban Forum, 20, 157-174. Retrieved from https://doi.org/10.1007/s12132-009-9060-2g

Turok, I., \& Watson, V. (2001). Divergent development in South African cities: Strategic challenges facing Cape Town. Urban Forum, 12(2), 119-138. https://doi.org/10.1007/s12132-001-0013-7

Uuemaa, E., Antrop, M., \& Marja, R. (2009). Landscape metrics and indices : An overview of their use in landscape research imprint/terms of use. Living Review in Landscape Research, 3, 1-28.

van Delden, H., \& van Vliet, J. (2008). Thematic priority: Global change and ecosystems calibration of the activity based METRONAMICA land-use model. Retrieved from http://www.noveltis.com/desurvey/ documentation/deliverables/DESURVEY_D1.2.3.7_Calibration_Report_AB_Metronamica.pdf

van der Ree, R., Jaeger, J. A. G., van der Grift, E. A., \& Clevenger, A. P. (2011). Effects of roads and traffic on wildlife populations and landscape function: Road ecology is moving toward larger scales. Ecology and Society, 16(1), 48-57.

Weng, Y. C. (2007). Spatiotemporal changes of landscape pattern in response to urbanization. Retrieved from http://ac.els-cdn.com/S0169204607000187/1-s2.0-S0169204607000187-main. pdf?_tid=e52d7c74-9e2f-11e6-a839-00000aab0f6c\&acdnat=1477784102_cf0d64cc6e5632dc224ab0dd0db651a8

Western Cape Provincial Treasury. (2012). Regional development profile: City of Cape Town, working paper, 57. Retrieved from https://www.westerncape.gov.za/assets/departments/treasury/dc0_city_ of_cape_town_sep-lg_profile_02_2013.pdf

Wilkinson, P. (2000). City profile Cape Town. Cities, 17(3), 195-205.

Wu, K., Kuo, H., \& Zhang, D. (2016). Monitoring landscapechanges of rural townships in the cold region of China using RS, GIS, and landscape metrics. Proceedings of the 2nd International Forum on Electrical and Automation, 368-372, Guangzhou, China. Retrieved from https:/www.google.co.za/url?s $\mathrm{a}=\mathrm{t} \& \mathrm{rct}=\mathrm{j} \& \mathrm{q}=\&$ esrc $=$ \&\&source=web\&cd=1\&cad=rja\&uact=8\&ved=0ahUKEwilqIbCjYHQAhU GB8AKHfJbCxUQFggaMAA\&url=http://www.atlantis-press.com/php/download_paper.php?id= 25847654\&usg=AFQjCNEDj9YJfF6okPdWaQyz-PMjRxUamA\&sig2=RVq3Ug9UnGB5oCki 